International Journal of Linguistics, Literature and Culture
Available online at https://sloap.org/journals/index.php/ijllc/
Vol. 7, No. 6, November 2021, pages: 499-505
ISSN: 2455-8028
https://doi.org/10.21744/ijllc.v7n6.1976

\title{
Electronic Guide-Translator Program for Independent Tourists
}

Alimova Kamola Tursunovna ${ }^{\text {a }}$

Article history:

Submitted: 27 September 2021

Revised: 18 October 2021

Accepted: 09 November 2021

\section{Keywords:}

guide-translator;

independent tourists;

multimedia;

service;

software;

tourist facilities;

\section{Corresponding author:}

Alimova Kamola Tursunovna,

Teacher, Translation department, UzSWLU, Uzbekistan.

Email address: kamola.alimova85@mail.ru

\begin{abstract}
The article discusses the creation of a multimedia electronic guide-translator program, which includes an electronic catalog and an audio description of a tourist object, as well as electronic functions for a convenient stay of a tourist in Uzbekistan. The paper presents the priorities of the multimedia electronic guide-translator program in the development of domestic tourism and the creation of an innovative approach in the tourism environment that facilitate the travel process by improving the quality of the development of the tourism sector in the Republic of Uzbekistan and providing services to visiting tourists.
\end{abstract}

International journal of linguistics, literature and culture (C) 2021. This is an open access article under the CC BY-NC-ND license (https://creativecommons.org/licenses/by-nc-nd/4.0/).

a Teacher, Translation department, UzSWLU, Uzbekistan 


\section{Introduction}

Peaceful life in our country, tolerance, and cohesion, national traditions and customs, patterns of handicrafts, hospitality peculiar to our people have led to the fact that Uzbekistan currently occupies a worthy place among the states with developed modern tourist infrastructure and innovative technologies. The tourism industry makes a worthy contribution to the development of our country. Today, one of the urgent tasks is to create all conditions for attracting tourists to the republic and developing domestic tourism (Novikova et al., 2015; Zharkova, 2012). Indeed, the development of this industry is an important source of the economy and occupies a leading place in the formation of GDP, ensuring employment, improving the welfare of the population.

\section{Materials and Methods}

Activities to develop and stimulate the tourism industry are carried out in all historical cities of Uzbekistan, which are known for the antiquity of their history, centuries-old traditions, and cultural values. The ongoing work to support and stimulate tourism gives positive results. Samarkand, Bukhara, Khiva, Shakhrisabz, and other cities with deep histories are some of the tourist cities of our country, which displays the world past, lifestyle, culture, spiritual values of our people. Despite this, the data on these unique cities are only partially covered. Today, in these cities, striking with a centuries-old, unique history - cultural monuments, there is a problem of the influx of internal and external tourists associated with the attraction and provision of services to tourists, as well as the lack of innovative technologies to solve them (Filatova, 2014; Novikova, 2015). The conducted study of these regions indicates the need to create and promote new electronic resources, that is, the creation of a national tourist product. Currently, interactive Verum QR programs have been launched at tourist sites in cities, but the information in them is presented only in two languages, Russian and English. This creates discomfort for tourists who speak other languages (Tsaur et al., 2010; Obenour et al., 2006).

During the preparation of scientific work with the territorial administration of the State Committee of the Republic of Uzbekistan for the Development of Tourism, consulting work was carried out. Currently, the problems, requirements, and proposals arising in the process of developing tourism potential in tourist cities of Uzbekistan have been studied. Due to the lack of a database of tourist sites and electronic catalogs in different languages and service facilities, the creation of a software program "multimedia electronic guide-translator" will have a positive impact on the development of tourism in Uzbekistan. Thanks to the development of the Internet and new innovative technologies, the number of independent tourists is growing. It is for independent tourists that our country is interesting, as many come to get a cultural holiday and in search of an adventure (Demidova, 2008).

What are independent tourism and independent tourist? Independent tourism (amateur, independent, free tourism) is an independent trip made for little money, often by refusing the services of tour operators, guides, and escorts. Independent tourists plan and carry out all their trips independently, they look for and live suitable in hotels and inns, but also in hostels, campsites, guesthouses, as well as in the homes of residents. They usually eat in the same place as the locals - in simple canteens and inexpensive restaurants (Zaitseva et al., 2017). They prefer to choose and visit tourist sites on their own without guides and refuse typical tourist programs. They refuse the services of travel agencies, operators, and guides-translators and independently plan their trips using various electronic resources. To implement this, it is necessary to create a tourist product - electronic software programs for tourist objects of the city.

The lack of new tourism products hurts the tourism business. It is also worth paying special attention to the question of specialists, since the problem of training guides-translators, who are the core of this sphere, is in a deplorable state (Qosimov et al., 2020; Kosimova \& Kosimov, 2020). As you know, any guide-translator is not just a translator, he is a specialist, an expert in the history, culture, and national values of our Motherland. Electronic programs that include data on tourist and service facilities of the city play an important role in improving the work of guides and interpreters. Currently, consumers have the opportunity to choose goods and services in all industries, the impact of which can be seen in the tourism sector. In which the demand of consumers is constantly changing because they are looking for new sensations. Another serious factor that causes the flow of tourists is that tourists come to get acquainted with the famous monuments of Uzbekistan and all the urban construction ensembles. But the possibility of transmitting information in full in the language that tourists understand about these objects is incredibly low. This will increase the need for electronic supply programs, including a database of multilingual tourist sites and their audio recording (Djabbarov, 2021; Turaev \& Patterson, 2020; Airey \& Shackley, 1997; Sulaiman \& Wilson, 2019).

The creation of the Electronic guide-translator program is due to the following factors: 
- the transition of the economy to market relations puts forward new requirements for the quality of services provided and various forms and methods of providing tourist services. The development of innovative technologies and the provision of services in the form of electronic programs will contribute to an increase in the influx of tourists to Uzbekistan.

- each guide-translator is not just a translator, he is a specialist in the history, culture, and national values of our Motherland. Electronic programs containing a database of tourist sites of the city play an important role in improving the work of guides and interpreters.

- considering that the importance of personnel training in the field of tourism, the electronic support program corresponding to international educational standards will contribute to improving the efficiency of the educational process of students studying in the direction of translation of higher educational institutions.

For the accelerated development of the tourism sector, the elimination of the above problems, it is important to create an electronic software program "multimedia guide-translator" for tourists visiting Uzbekistan within the framework of project studies, which in the future will serve as the basis for the creation of such programs in other tourist cities of our country. The state programs created in our country, which have developed the foundations and outlined the prospects for development, decision-making on this industry at the state level indicate the expansion of opportunities in this area. It is important to increase the flow of tourists, improve the quality of their service, provide qualified personnel, develop new electronic programs, thanks to which it will be possible to successfully cope with the tasks (Oarga-Mulec et al., 2017; Apollo, 2014).

The creation of this product will create conditions for attracting tourists to Uzbekistan, strengthening the potential of domestic tourism, improving the quality of service for tourists, facilitating the tourist process, and providing complete and reliable information about tourist sites in Uzbekistan, communicating with the local population. Also, the project products will help improve the work of guide translators, to obtain operational information about tourist sites and service points (currency exchange, taxi services, canteens, hotels, etc.). This project will allow the development of the tourism industry in our country, as well as selling, finished tourist products in the domestic and foreign markets (Pizam et al., 1978; Chiao et al., 2018). In addition, based on the created electronic software program "multimedia guide-translator" for tourists who came to Uzbekistan. With the help of the created electronic software program "multimedia guide-translator" for tourists visiting Uzbekistan, it is provided:

- promotion of tourism products of the Republic of Uzbekistan in international and domestic tourism markets;

- increase in the influx of international tourists;

- creating the convenience of communication between tourists and locals;

- strengthening the image of the country as safe for travel and recreation;

- creating favorable conditions for tourists and local visitors for the development of domestic and foreign tourism in Uzbekistan;

- providing complete and accurate information about tourist sites in the form of written and audio recordings in different languages without the services of a guide-interpreter for tourists;

- improving the competitiveness and quality of services provided;

- providing quick location information (address, location region...) service points for tourists visiting our country (hotels, canteens, exchange offices, taxi booking....);

- providing translation guides with operational information about tourist sites;

- promotion of the national tourism product on the world market;

- use as a necessary electronic textbook for improving the system of training, retraining, and advanced training of personnel for the tourism industry;

- promoting the tourism potential of Uzbekistan abroad and attracting foreign tourists.

The development of tourism has a positive effect on the activation of financial processes. Improving the efficiency of domestic tourism depends on peace, security, socio-economic situation because tourism is one of the global socioeconomic spheres of the modern world. The demonstration of our internal potential is the improvement of historical monuments, attractions, natural landscape, material, cultural and architectural appearance to the level of world standards, the activation of travel companies, hotel and other communication networks, transport infrastructure, catering and entertainment facilities, the activation of medical and sports areas (Wang et al., 2020; Sumadi, 2016; Wendri et al., 2019).

Tursunovna, A. K. (2021). Electronic guide-translator program for independent tourists. International Journal of Linguistics, Literature and Culture, 7(6), 499-505. https://doi.org/10.21744/ijllc.v7n6.1976 
When creating a program to provide a multimedia electronic guide-translator for tourists visiting Uzbekistan using information technology, special attention will be paid to achieving the following goals:

1) Translation of materials about tourist sites of Uzbekistan into different languages and translation into electronic (recording and photo) version.

2) Attracting tourists to this territory.

3) Preparation of audio recordings for tourists based on materials about tourist sites in Uzbekistan

4) Preparation of ready-made speech expressions characteristic of Uzbek speech etiquette and its equivalent in different languages used during the trip.

5) Provision of an electronic database in various languages about service facilities.

In this regard, work will be carried out in the following areas:

1) Collection of materials about tourist sites of Uzbekistan, acquaintance, and systematization, meeting with historians and qualified guides-translators, description of tourist sites.

2) Translation of materials into different languages, preparation of information in electronic form, formatting of photographic materials.

3) Creation of multimedia guide-translator software from the collected materials, preparation for sale in the domestic and foreign markets, transmission in the form of an application for gadgets, recording on DVDs, and popularization in higher educational institutions.

Multimedia software for an electronic guide-translator for tourists visiting Uzbekistan includes the following sections:

Main section

1) Electronic catalog in different languages containing information and photos of tourist sites of Uzbekistan;

2) Ready-made speech expressions characteristic of Uzbek speech etiquette used in the tourist process, and their equivalents in different languages;

3) The audio recording in different languages, containing information about them in the process of viewing tourist sites.

\section{Additional section}

Electronic database of service facilities in tourist cities of Uzbekistan in different languages.

When creating an electronic program for providing a multimedia guide-translator for tourists - a tourist product, the following tasks will be performed in 2 stages;

At the first stage, the following work will be performed

1) A work plan will be drawn up and a concept will be developed.

2) Materials on the objects of tourism and service of tourist cities will be collected, studied, and systematized.

3) Practical tasks will be completed, which will be carried out in tourist facilities.

4) The script for the software of the electronic multimedia guide-translator will be recorded.

5) The lexical minimum of the phrasebook has been selected.

6) A script will be written for audio and photo materials.

At the second stage, the following work will be performed

1) The prepared materials for the multimedia software of the guide-translator, as well as materials about tourist and service facilities, materials for the phrasebook, materials for audio recording, will be translated into English, German, French, Russian, Korean, Spanish, and Chinese;

2) An audio recording will be prepared for the electronic guide-translator software. 
3) A multimedia application for electronic support and a mobile application for guides-translators and tourists visiting Uzbekistan will be developed.

The multimedia guide-translator for tourists visiting Uzbekistan will contain the following sections:

Main section

1) The electronic catalog will contain general information about the tourist sites of Uzbekistan and photo materials. A tourist wishing to visit a tourist object located in Uzbekistan can get acquainted with tourist objects through this electronic catalog and independently compile a tourist program by selecting the tourist objects of interest to him also, guide-translators can use the electronic catalog to obtain additional information about the work. Students studying in the translation direction at the university can use it as an additional source of learning in the course of practical classes.

2) An electronic phrasebook will allow a tourist visiting Uzbekistan to communicate directly with residents. This phrasebook will present ready-made speech expressions characteristic of Uzbek speech etiquette and their equivalents in different languages. It is assumed that these samples of speech etiquette will be used as the main means of speech recognition for foreigners.

3) The audio recording will allow you to listen to the information in different languages while visiting tourist sites in cities.

\section{Additional section}

An electronic database of service facilities in Uzbekistan in different languages will provide tourists with additional comfort. A multimedia guide-translator for tourists visiting Uzbekistan and a mobile application will be available in Uzbek, Russian, English, German, French, Spanish, Chinese and Korean.

\section{Results and Discussions}

The role of the service sector in improving the level and quality of people's lives is invaluable. Therefore, the service sector in the world is steadily developing. The economic reforms carried out in our country, like all spheres of the economy, have led to fundamental changes in the service sector. Diversification of tourism products and services aimed at various segments of the tourism market development of domestic tourism, providing stimulation of the activity of tourism entities aimed at meeting the needs for tourism services within the republic, promotion of tourism products of the Republic of Uzbekistan in international and domestic tourism markets, strengthening the image of the country as safe for travel and recreation, improving the system of training, retraining and advanced training of personnel for the tourism industry. The created program of providing a multimedia electronic guide-translator will help Uzbekistan attract potential tourists, improve the quality of service and improve the work of guide-translators (Ap \& Wong, 2001; Mackenzie \& Raymond, 2020).

\section{Conclusion}

Currently, it is impossible to imagine the tourism sector without electronic resources. The analysis shows the imperfection of the regulatory framework governing the tourist network, the lack of rules for the provision of individual tourist services, in particular, the software "multimedia electronic guide translator" and the database of electronic information systems serving tourists.

\section{Conflict of interest statement}

The author declared that he have no competing interest.

Statement of authorship

The author has a responsibility for the conception and design of the study. The author have approved the final article.

Tursunovna, A. K. (2021). Electronic guide-translator program for independent tourists. International Journal of Linguistics, Literature and Culture, 7(6), 499-505. https://doi.org/10.21744/ijllc.v7n6.1976 
Acknowledgments

I am grateful to two anonymous reviewers for their valuable comments on the earlier version of this paper. 


\section{References}

Airey, D., \& Shackley, M. (1997). Tourism development in Uzbekistan. Tourism Management, $18(4), 199-208$. https://doi.org/10.1016/S0261-5177(97)00006-X

Ap, J., \& Wong, K. K. (2001). Case study on tour guiding: Professionalism, issues and problems. Tourism management, 22(5), 551-563. https://doi.org/10.1016/S0261-5177(01)00013-9

Apollo, M. (2014). Dual pricing-two points of view (citizen and non-citizen) case of entrance fees in tourist facilities in Nepal. Procedia-Social and Behavioral Sciences, 120, 414-422. https://doi.org/10.1016/j.sbspro.2014.02.119

Chiao, H. M., Chen, Y. L., \& Huang, W. H. (2018). Examining the usability of an online virtual tour-guiding platform for cultural tourism education. Journal of Hospitality, Leisure, Sport \& Tourism Education, 23, 29-38. https://doi.org/10.1016/j.jhlste.2018.05.002

Demidova, T.V. (2008). Structuring excursion discourse from the standpoint of frame analysis. Cognitive linguistics issues, (4).

Djabbarov, IKHTIYOR (2021). Problems of Organization of Tourist Zones in Free Economic Zones of Bukhara. CENTER FOR SCIENTIFIC PUBLICATIONS (buxdu.uz) , 5 (5).

Filatova, N.V. (2014). Discourse in the sphere of tourism in pragmatic and linguistic aspects. Moscow .

Kosimova, S. H., \& Kosimov, L. M. (2020). Principles of forming a garden-park landscape design around historical monuments of the fergana valley. ACADEMICIA: An International Multidisciplinary Research Journal, 10(6), 1582-1589.

Mackenzie, S. H., \& Raymond, E. (2020). A conceptual model of adventure tour guide well-being. Annals of Tourism Research, 84, 102977. https://doi.org/10.1016/j.annals.2020.102977

Novikova, E. Yu. (2015). Linguocultural Dimension Of The Internet Space Of The Excursion Discourse (on the example of the genre "Web site of the excursion bureau"). In Language and Culture in the Age of Globalization (pp. 76-86).

Novikova, E. Yu., Mityagina, V. A., \& Gureeva, A. A. (2015). Typology of communicative actions in excursion discourse. Bulletin of the Volgograd State Pedagogical University, (7 (102)).

Oarga-Mulec, A., Jenssen, P. D., Klemenčič, A. K., Uršič, M., \& Bulc, T. G. (2017). Zero-discharge solution for blackwater treatment at remote tourist facilities. Journal of Cleaner Production, 166, 798-805. https://doi.org/10.1016/j.jclepro.2017.08.002

Obenour, W., Patterson, M., Pedersen, P., \& Pearson, L. (2006). Conceptualization of a meaning-based research approach for tourism service experiences. Tourism management, 27(1), 34-41. https://doi.org/10.1016/j.tourman.2004.07.008

Pizam, A., Neumann, Y., \& Reichel, A. (1978). Dimentions of tourist satisfaction with a destination area. Annals of tourism Research, 5(3), 314-322. https://doi.org/10.1016/0160-7383(78)90115-9

Qosimov, L. M., Qosimova, S. F., \& Tursunov, Q. Q. (2020). Specific aspects of using Ferghana region's pilgrims for touristic purposes. Academic research in educational sciences, (3).

Sulaiman, M. Z., \& Wilson, R. (2019). Translation and tourism: Strategies for effective cross-cultural promotion. Springer.

Sumadi, K. (2016). Tourism development basis in traditional village of Kuta. International Journal of Linguistics, Literature and Culture, 2(3), 124-132. Retrieved from https://sloap.org/journals/index.php/ijllc/article/view/124

Tsaur, S. H., Yen, C. H., \& Chen, C. L. (2010). Independent tourist knowledge and skills. Annals of Tourism Research, 37(4), 1035-1054. https://doi.org/10.1016/j.annals.2010.04.001

Turaev, H., \& Patterson, I. (2020). Priority Directions for Tourism Development in Uzbekistan. Indonesian Journal of Law and Economics Review, 8, 10-21070.

Wang, W., Ying, S., Mejia, C., Wang, Y., Qi, X., \& Chan, J. H. (2020). Independent travelers' niche hotel booking motivations: the emergence of a hybrid cultural society. International Journal of Hospitality Management, 89, 102573. https://doi.org/10.1016/j.ijhm.2020.102573

Wendri, I. G. M., Bakta, I. M., Suprapti, N. W. S., \& Ardika, I. W. (2019). Various factors contributive toward tourist intention in enjoying wellness tourism. International Journal of Linguistics, Literature and Culture, 5(3), 61-70. https://doi.org/10.21744/ijllc.v5n3.646

Zaitseva, N. A., Larionova, A. A., Yakimova, N. S., Leukhova, M. G., \& Radina, O. I. (2017). Methodological aspects of foreign language teaching in the preparation of the tour guides. Modern journal of language teaching methods, 7(4), 399-409.

Zharkova, U.A. (2012). The professional linguistic personality of the guide: the discursive aspect. Linguistic aspects of the study of personality identity in a changing world: the collective. monograph Chelyabinsk, 109-132.

Tursunovna, A. K. (2021). Electronic guide-translator program for independent tourists. International Journal of Linguistics, Literature and Culture, 7(6), 499-505. https://doi.org/10.21744/ijllc.v7n6.1976 